\title{
Reward Systems as Determinant Of Talent Management in Public Universities in Kenya
}

\author{
Prof. R.W Gakure, Alice Wangui Kamau, Dr A.G. Waititu \\ (Jomo Kenyatta University of Agriculture and Technology, Kenya) \\ (Jomo Kenyatta University of Agriculture and Technology, Kenya) \\ ( Jomo Kenyatta University of Agriculture and Technology, Kenya)
}

\begin{abstract}
The aim of this study was to determine whether reward systems influence talent management in public universities in Kenya. Literature has revealed that on one hand talent management has taken a slow pace or has lacked in institutions of higher education compared to the private sector on the other hand studies have established that reward systems in public institutions do not match the private sector. The sample was $n=249$ from public universities in Kenya. Factor analysis revealed a determinant of 0.144; Bartlett's test was significant $p<0.05$ with KMO value of 0.759 . Factor analysis revealed one item with a loading value below 0.4 as recommended by Pallant, (2005); hence this item was eliminated in the analysis; all other remaining components were retained for analysis. The data had a Cronbach's alpha of 0.764; hence the 8 items extracted were determined to be reliable. Data analysis revealed a strong positive relationship $(r(249)=0.529, p$-value $<0.05)$ indicating a significant linear relationship between reward systems and talent management.
\end{abstract}

Keywords: Reward system, Talent Management, Kenyan Public Universities, Institutions of Higher Education

\section{Introduction}

Academic staff are the most important human resources in higher institutions of learning. The performance of academic staff to a large extent determines the quality of the students and as Rowley (2009) pointed out the institutions of learning have implicit or explicit mission to offer a high quality learning experience to all their students; the academic staff provide this interface and to ensure quality the staff need to be motivated well. Proper reward system management amongst other strategies ensures motivation. Dessler (2003) clearly stated that, without increased motivation and morale of the employees, organizations risk losing valuable employees and will be at a disadvantage in attracting potential top talents.

Literature has established that reward systems have been an issue in higher institutions of learning; for instance Broardman and Ponomariov (2007) citing Boyer (1990) observed that the universities still use traditional reward systems to compensate articles published in refereed academic journals, book chapters, and academic monographs, this do not match up with the daily tasks performed such as creation of knowledge, teaching, technology transfer, and economic development. In addition Bayissa \& Zewdie (2010) study indicated that opportunity for growth and career development (further education), job security and job freedom are some of the major rewards availed to academic staff; however available reward systems of the institution other than the basic salary are poor. Public institutions compared relatively to private institutions as noted by (Thornton, 2011) have seen the average faculty salaries fall; consequently making it difficult for publics to attract and retain top professors.

Studies have highlighted the benefits of rewards to an organization or institutions. Torrington (2008) argued that the purpose of reward system is to attract and retain suitable employees; as a caution he argued that, employers who develops a reputation as cheap are unlikely to be desirable in the job market; hence ends up with people that nobody else desires. Bratton and Gold (2007) collaborated this observation by noting that rewards can serve the purpose of attracting prospective job applicants, retaining valuable employees, motivating employees, as well as assisting in achieving human resource objectives and obtaining competitive advantage. This was collaborated by Muhamad, Bano \& Rehman (2010) argument that employee performance and talent retention can be enhanced by cogitation through incentives, monetary benefits and rewards. Similarly, Bayissa \& Zewdie (2010) acknowledged that the main purpose for the reward system is to attract and retain competent employees rather than the one to motivate.

A study Shahzad et al. (2010) found that Universities needed to offer a competitive compensation and workload for attracting and retaining competent faculty in Higher education; this connection was important because it enhanced the commitment of faculty to performance and acted as a key factor to improve academic quality. Furthermore, Armstrong (2008) suggested that to achieve long lasting motivation for the employees, attention must be paid to both monetary and non monetary rewards. Similarly Rowley (2009) noted that for academic staff to offer high quality learning and manage their learning experiences their motivation was crucial. 
For a reward system to be motivational it should satisfy a number of criteria; have value, be large enough to have impact, be understandable, be timely, should be durable and cost efficient ( Van der Stede, 2007).

\section{Research gap}

The studies; Muhamad et al. (2010); associated reward systems to performance. The studies that highlight that reward systems are intended to attract and retain suitable employees include (Torrington, 2005; Bratton \& Gold, 2007; Muhamad, Bano \& Rehman, 2010; Bayissa \& Zewdie, 2010) however other studies related reward systems to motivation; (Van der Stede, 2007; Armstrong, 2008; Torrington et al. 2008 \& Rowley, 2009). Bayissa \& Zewdie, (2010) study focused on academic staff reward related problems and examined the effectiveness of both financial and nonfinancial reward systems. These studies were not linked to talent management.

\subsubsection{Reward System Factor Analysis}

Factor analysis was performed using all items that make up reward system. Prior to PCA the suitability of the data for factor analysis was assessed (Pallant, 2005). To test for appropriateness of factor analysis KaiserMeyer- Oklin (KMO) and Barlett's test of Sphericity were used.

Table1: KMO and Bartlett's Test

KMO and Bartlett's Test

\begin{tabular}{|c|c|c|}
\hline \multicolumn{2}{|c|}{ Kaiser-Meyer-Olkin Measure of Sampling Adequacy. } & .759 \\
\hline \multirow[t]{3}{*}{ Bartlett's Test of Sphericity } & Approx. Chi-Square & 473.771 \\
\hline & df & 36 \\
\hline & Sig. & .000 \\
\hline
\end{tabular}

Table 1 show (KMO) Measure of Sampling Adequacy was 0.759, was above the recommended value (Hair et al., 1998; Pallant, 2005). In addition, Bartlett's Test of Sphericity reached statistical significance at $(p<0.05)$ which indicated that the matrix is not an identity matrix hence indicating appropriateness of factor analysis. After assessment of the suitability of data for factor analysis; Principal Component Analysis was applied to extract components. Table 2 shows the factors extracted for the independent variable reward system.

Table 2: Component Matrix

Component Matrix

Component

\begin{tabular}{lr}
\hline Comfortable with Reward System Management & .685 \\
My Income meets Personal Developmental Needs & .684 \\
Equity and Fairness in Compensation and Benefits & .665 \\
Satisfied with the level of Recognition for my Performance & .657 \\
compensated for extra work & .645 \\
promotions are done fairly & .553 \\
Engage in part timing because salary is not adequate & .497 \\
My institution pay Higher compared to Others & .486 \\
My salary is adequate & .353 \\
\hline
\end{tabular}

Extraction Method: Principal Component Analysis.

a. 1 components extracted.

Table 3 shows one factor with a loading less than the recommended threshold of 0.4, (Beaumont, 2012).The factor italiced was removed from analysis. Factor analysis as noted by Pallant (2005) is possible when there are large numbers of related variables. 
Reward System Reliability Analysis

Table 4 Reliability Analysis

\begin{tabular}{lc}
\hline \multicolumn{2}{c}{ Reliability Statistics } \\
\hline Cronbach's Alpha & $\mathrm{N}$ of Items \\
.759 & 9 \\
\hline
\end{tabular}

To test for the reliability of reward system questionnaire Cronbach's alpha was calculated giving a value of 0.759. Hair et al., (1998); Maizura et al., (2009) recommended a Cronbach alpha value of 0.70. Other studies have recommended a reliability coefficient of 0.50 or 0.6 (Nunnally, 1967; Davis and Cosenza, 1988).

Descriptive Analysis

Table 5 shows the percentage respondents' rates for the reward systems factors.

Table 5: Reward system

\begin{tabular}{|c|c|c|c|c|c|c|}
\hline Code & Factors related to Reward systems & HA(5) & $\mathbf{A ( 4 )}$ & $\mathbf{N}(3)$ & $\mathbf{D}(2)$ & HD(1) \\
\hline RS1 & $\begin{array}{l}\text { I am comfortable with management of reward } \\
\text { system }\end{array}$ & 12.4 & 23.7 & 24.1 & 22.9 & 16.9 \\
\hline RS2 & $\begin{array}{l}\text { Compensation and benefits systems ensure } \\
\text { equity and fairness }\end{array}$ & 6.0 & 22.1 & 26.9 & 24.1 & 20.9 \\
\hline RS3 & My income enables me meet my personal needs & 10.0 & 26.5 & 28.9 & 24.5 & 10.0 \\
\hline RS5 & $\begin{array}{l}\text { I am compensated for any extra work done } \\
\text { outside my routine work }\end{array}$ & 10.4 & 22.1 & 28.5 & 28.5 & 10.4 \\
\hline RS6 & My institution pay higher compared to others & 6.4 & 12.9 & 38.2 & 30.1 & 12.4 \\
\hline RS 7 & $\begin{array}{l}\text { I am satisfied with the level of recognition } \\
\text { offered for my performance }\end{array}$ & 10.0 & 20.9 & 29.7 & 28.9 & 10.4 \\
\hline RS8 & Promotions are done fairly & 4.8 & 29.3 & 25.7 & 31.3 & 8.6 \\
\hline \multirow[t]{2}{*}{ RS9 } & $\begin{array}{l}\text { I engage in part timing because my salary is not } \\
\text { adequate }\end{array}$ & 33.3 & 34.9 & 11.6 & 9.6 & 10.4 \\
\hline & Averages & 12.78 & 26.87 & 25.39 & 23.189 & 11.67 \\
\hline
\end{tabular}

\section{i. Comfortable with Management of Reward Systems (RS1)}

The findings on this factor indicated that a total $39.8 \%$ of the respondents disagreed while $36.1 \%$ of the respondents agreed that they are comfortable with management of reward systems. These findings are in conformity with Bayissa and Zewdie, (2010) results which indicated that academic staffs in their study were not satisfied with the overall reward system. Similarly Kiptebut, (2010) findings indicated that 86.4\% respondents from public universities were more dissatisfied with their pay than $51.7 \%$ respondents from private universities. As Bratton and Gold, (2007) noted reward can serve the purpose of attracting prospective job applicants, retaining valuable employees, motivating employees, as well as assist in achieving human resource objectives and competitive advantage. This has implication that if reward systems are not attractive then attracting and retaining staff becomes a challenge in public universities.

\section{ii. Compensation and Benefits Systems Ensure Equity and Fairness (RS2)}

Majority of the respondents with a $45 \%$ representation disagreed that the compensation and benefits ensure equity and fairness; $28.1 \%$ agreed there was equity and fairness. Bayissa and Zewdie (2010) had similar results where majority of the academic staff who participated in their study felt there was no transparency and fairness in the reward systems. In addition Kiptebut, (2010) findings indicated that the majority of the academics felt that they were not fairly rewarded considering the responsibilities they undertook. Similarly Kamoche et al. (2004) found that there were unfair practices and lack of clear and consistent wage policies in the public sector in Kenya. Adam's Equity theory, (1963) demonstrated that people tend to be attracted to institutions where they perceive that there is equity and fairness in regard to compensation compared to their contributions to the institutions. If this is not the case the rates of attraction and retention tend to be low and vice versa.

\section{iii. Compensated for any Extra Work done outside my Routine Work (RS5)}

Results showed that academics were not compensated for any extra work done an indication that there was an element of exploitation in public universities; with a majority $38.9 \%$ disagreeing and $32.5 \%$ agreeing. 
These results are collaborated by Mihyo (2007) study where the academic staff under the study responded to increased workloads due to the introduction of second stream courses most of which were run in the evening and for which the institutions are adequately paid by the students, but in some institutions staff were not been paid for extra work for periods close to two years. Similarly, Schwartz, Skinner \& Bowen (2009) found out that faculty members were involved in decision-making and took on leadership roles in addition to their work responsibilities, with little recognition for the time involved.

\section{iv. My Institution pay Higher Compared to Others (RS 6)}

Majority $(42.5 \%)$ of the respondents disagreed that their institutions pay higher than other institutions $19.3 \%$ were of the opinion that they were paid more compared to others. In public universities salary scales are determined by the government and varies with the positions held. The differences in payments amongst the institutions occur in part time payments. Zhang and Liu (2010) also found that the composition of faculty determines faculty salary levels. Cheslock and Callie, (2011) found that there were less salary inequality in public universities and this was attributed to the greater dissemination of salary information in public institutions.

\section{v. I am Satisfied With The Level of Recognition Offered for my Performance (RS 7)}

As the table shows the majority (39.3\%) of the respondents said they disagreed with level of recognition offered for the performance, $30.9 \%$ agreed they were satisfied. This confirms results of Bayissa and Zewedie (2010) where lack of recognition for performance was found to be amongst the most prevalent problems of reward system. Kipkebut, (2010) citing Kigotho, (1994); Makabila, (2006) \& Mkawale, (2007) argue that dissatisfaction with pay has resulted to frequent strikes and closure of Kenyan public universities consequently lecturers look for other means of supplementing their income hence compromising the delivery of teaching.

\section{vi. Promotions Are Done Fairly (RS 8)}

On this factor a majority of the respondents disagreed that promotions are done fairly with a $39.3 \%$ of the respondents and $30.9 \%$ agreed that promotions are done fairly. The unfairness comes about due to the many requirements put in place which are beyond the lecturers' ability. Tettey (2006) found that promotional procedures in African universities are long, stressful and cumbersome for instance possession of a doctorate as a prerequisite for promotion beyond the position of a lecturer. In addition, Kipkebut, (2010) noted that promotion for academic employees is dependent on teaching, research and publications. These requirements which are not reasonable provide little chance for academic staff being promoted.

\section{vii. I am Engaged in Part Time Because My Salary is not Adequate(RS 9)}

From the table above $68.2 \%$ agreed that they engage in part time because the pay is not adequate while $20 \%$ disagreed with this statement. These results indicate that part timing is on the rise and quality is definitely compromised. Part timing or moon lighting as it is referred by Ishengoma (2007) is one of the internal brain drain which is a consequence of low remuneration among other reasons. Literature has further supported this finding with (Abagi, 1998; Tettey 2006) as cited by Kipkebut (2010) arguing that academic employees who are unable to get attractive opportunities elsewhere are actively engaged in professional and non professional activities within and outside their universities to supplement their income. Consequently besides quality issues in teaching, researches are also compromised. Kipkebut (2010) observed that quality of research produced in African universities has been found to be poor not only due to lack of adequate facilities, but also because academics are not well prepared to do research.

The overall outcome suggests that reward system is an issue that requires serious consideration. According to Torrington (2008), reward system is intended to attract and retain suitable employees; an employer who develops a reputation as cheap is unlikely to be desirable in the job market because potential employees will think it does not reward efforts; hence the organization ends up with people that nobody else wants. This is in tandem with Muhamad, Bano \& Rehman, (2010) observation that employee performance and talent retention can be enhanced by cogitation through incentives, monetary benefits and rewards.

According to Adams Equity Theory (1963) most individuals attempt to achieve equity by adjusting their own inputs and outcomes, or attempting to change the inputs or outcomes of the comparison others. Individuals can use behavioral processes or cognitive processes in order to attempt to restore equity; these include decreasing productivity at work, finding a new job, asking for a wage increase amongst other reasons.

\section{Correlation Analysis}

What is the Relationship Between Reward System and Talent Management

The figure suggests that the relationship between reward system and talent management is positive since the points are scattered from left to right, (Pallant, 2005) 


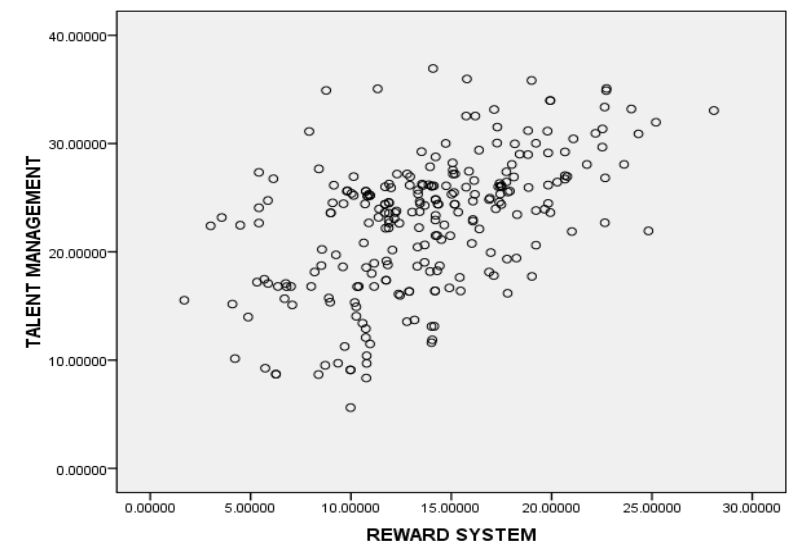

Figure 1: Correlation Reward System Vs Talent Management

Table 6 shows the Pearson correlation calculated for the relationship between reward systems and talent management. A strong positive relationship was found $(\mathrm{r}(249)=0.529$, $\mathrm{p}$-value $<0.05)$ indicating a significant linear relationship between the two variables. This means that if the value of reward system variable increases, the value of talent management variable also increases. Green, Salkind, and Akey, (2000) highlighted that correlation coefficient of $0.10,0.30$ and 0.50 regardless of the sign, are interpreted as small, medium and large coefficients respectively.

Table 6: Correlation Coefficient Of Reward System vs Talent Management Correlations

\begin{tabular}{llcc}
\hline & & Reward System & Talent Management \\
\hline Reward System & Pearson Correlation & 1 & $.529^{* *}$ \\
& Sig. (2-tailed) & & .000 \\
Nalent Management & Pearson Correlation & 249 & 249 \\
& Sig. (2-tailed) & $.529^{* *}$ & .000 \\
& $\mathrm{~N}$ & 249 & 249 \\
\hline
\end{tabular}

Regression Analysis: How does Reward System influence Talent Management?

The estimated regression equation was used to predict the value of the dependent variable talent management given values for the independent variable (reward system). To determine how well reward systems can predict talent management the regression equation used was;

$y=\alpha_{2}+\beta_{2} x_{2}+e$

where; $\beta_{2}$ is the coefficient of correlation, $x_{2}$ is reward systems and $y$ is talent management. The independent variables; leadership, academic workload and work force attributes are held constant.

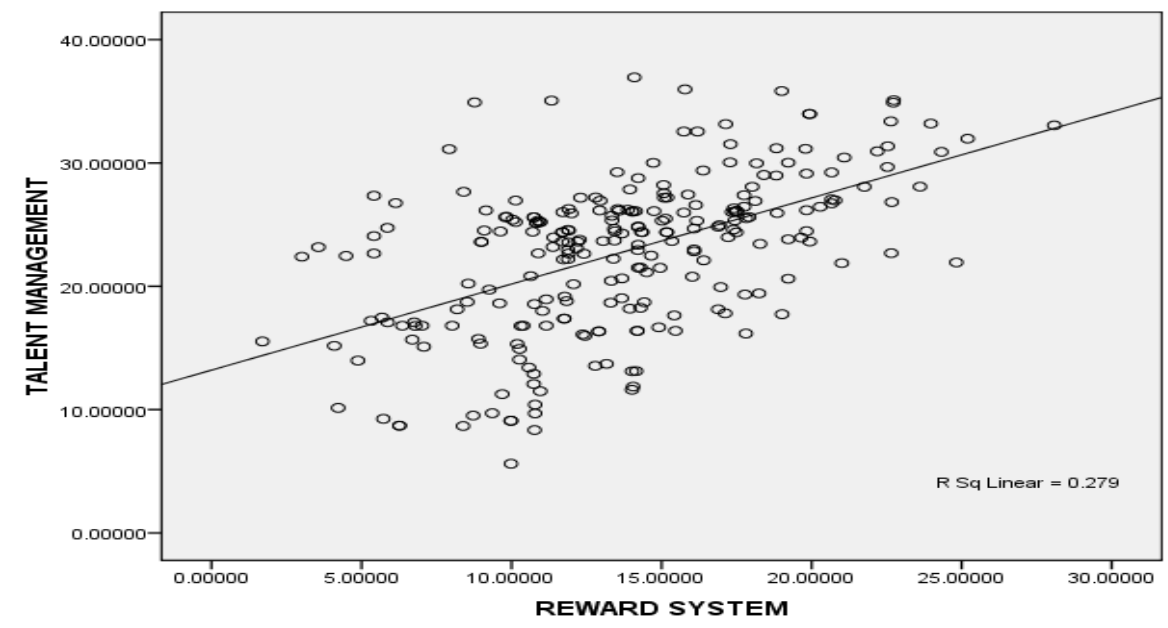

Figure 2: regression line between reward system and talent management 
Figure 2 represents the regression line graphically. The line is diagonal reflecting a positive linear relationship between talent management and reward system; this suggests a positively sloped regression line; hence satisfying the assumption of linearity in a simple regression model.

Table 7: Model of Fit between Reward System and Talent Management

\begin{tabular}{lccc}
\hline Model & $\mathrm{R}$ & $\mathrm{R}$ Square & Adjusted R Square \\
& .529 & .279 & .276 \\
\hline
\end{tabular}

The R squared (coefficient of determination) from table 7 indicates how much of dependent variable (talent management) can be explained by independent variable reward system. In this case $27.6 \%$ of the total variation in Talent Management can be explained by the reward systems. This reflects the overall strength of association between reward system and talent management and not the extent of the association.

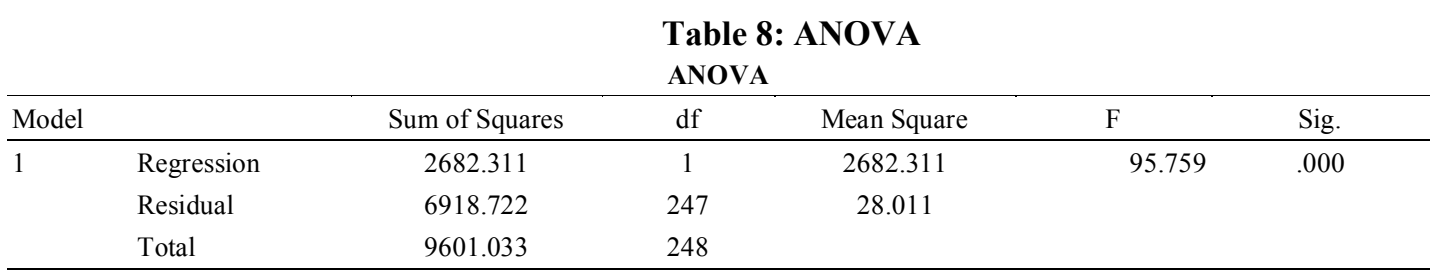

The null hypothesis tested was that the reward system in the regression model is not statistically fit to predict the outcome variable (talent management). Table 8 show that the F-test is statistically significant at $\mathrm{p}$ value is equal to 0.001 . Regression model is statistically fit when $p<0.05$. The ANOVA table indicates that the regression model can predict the outcome variable significantly at 0.001 hence the null hypothesis is rejected. The conclusion is that reward system can predict the outcome variable (talent management) at $\mathrm{p}=0.001$ level of significant with a $95 \%$ level of confidence.

\section{Determining the Regression Equation between reward system and talent management}

Table 9: Regression Coefficients

\begin{tabular}{|c|c|c|c|c|c|}
\hline \multirow[b]{2}{*}{ Model } & \multicolumn{5}{|c|}{ Unstandardized Coefficients Standardized Coefficients } \\
\hline & $\mathrm{B}$ & Std. Error & Beta & $\mathrm{t}$ & Sig. \\
\hline 1 (Constant) & 13.204 & 1.034 & & 12.771 & .000 \\
\hline Reward System & 698 & .071 & .529 & 9.786 & .000 \\
\hline
\end{tabular}

The regression model $y=\alpha_{2}+\beta_{2} x_{2}+e$; shows $\alpha$ is the constant represented by $13.204, \beta$ is represented by 0.698 , this value indicates the steepness of the regression line or how much the predicted value of the dependent variable (talent management) increases when the value of the independent ( reward system) variable increases. From table 9 reward systems contribute significantly to the model at $\mathrm{p}=0.001$. The regression equation takes the form; predicted variable (talent management) $=$ intercept + slope $*$ reward system. According to Field, (2005) the slope indicates how steep the regression line is; the intercept is where the regression line strikes Y axis. Therefore; Talent Management $=13.204+0.698^{*}($ Reward System $)$. For each Reward system value substituted and the Talent Management value that results provides an ordered pair that falls on the regression line. This mean for every unit increase in reward system there is a 0.698 change in talent management.

To test whether the regression coefficient for reward system was significantly different from zero a t test was determined at $5 \%$ level of significance. The null hypothesis tested was; reward system (independent variable) has no significant influence on talent management. That is

$\mathrm{H}_{0} ; \beta 2=0$ otherwise $\mathrm{H}_{A} ; \beta 2 \neq 0$; where $\beta 2$ is the regression coefficient of reward systems.

The coefficient table 9 indicates that the calculated t-value for reward system equals 9.786 , and is statistically significant at $\mathrm{p}$-value 0.001 ; the $\mathrm{t}$ crit $=\mathrm{t}_{247}(0.975)=1.960$; the null hypothesis was rejected and the conclusion was reward system has a significant positive influence on talent management.

\section{Conclusion and Recommendations}

It was also noted that most public universities are committed to retaining academic staff. However, the study revealed that most of the academics staff were not comfortable with management of reward systems citing inequality and unfairness, inadequate pay; a reason associated with higher rates of part timing to supplement the 
income. This also explains the lack of time for research and publications, personal engagement and self development. To contain the academic staff in their institutions there is need to pay them adequately; consequently improve on quality of teaching and research. Proper management of reward systems is one of the strategies for retaining employees.

\section{Reference}

[1]. Abagi, J O., Nzomo, J. \& Otieno, W. (2005). Private higher education in Kenya, in N. V. Varghese Higher education and specialized training: New trends in higher education. Paris, UNESCO: International Institute for Educational Planning.

[2]. Adams, (1963). Adams' Equity Theory. http://www.Mindtools.com/pages/article/newLDR 96.htm.

[3]. Adams, John S. (1963). Towards an Understanding of Inequity. Journal of Abnormal and, Social Psychology, 67(5), 422-436.

[4]. Alexander, F. (2001). The silent crisis: The relative fiscal capacity of public universities to compete for faculty. The Review of Higher Education, 24(2), 113-129.

[5]. Armstrong, M. (2006).A Hand Book of Human Resource Practice. Kogan Page limited London \& philadephia.

[6]. Bayissa, W. \& Zewdie S. (2010). Academic Staff Reward System. College of Business and Economics Jimma University.

[7]. Boardman, P. C. \& Ponomariov, B. L. (2007). Reward Systems and NSF University Research Centers: The Impact of Tenure on University Scientists'Valuation of Applied and Commercially Relevant Research The Journal of Higher Education, Vol. 78, No. 1 (January/February 2007) Ohio State University.

[8]. Boyer, E. L. (1990). Scholarship reconsidered: Priorities of the professoriate. Princeton, NJ: Carnegie Foundation for the Advancement of Teaching.

[9]. Bratton, J. and Gold, J., (2007). Human Resource Management: Theory and Practice. New York: Palgrave Macmillan Ltd.

[10]. Cheslock, J.J. \& Callie, T.M. (2011).How Do Public Higher Education Institutions Adjust Their Salary Structure and Faculty Composition in Response to Financial Challenges? S.P 2011 Working Paper No. 11.

[11]. Economics of Education Review, 29, 543-552.

[12]. Field, A. P.(2005). Discovering Statistics Using SPSS. $2^{\text {nd }}$ edition, London: Sage.

[13]. Gogia, P. (2010).Theory of Motivation. Retrieved from http://www.businessihub.com/equity-theory-of-motivation/.

[14]. Green, S.B., Salkind, N.J. \& Akey, T.M. (2000). Using SPSS for Windows: Analyzing and Understanding.Data. 2nd edition, Prentic-Hall, Upper Saddle River, NJ.

[15]. Hair, J. F., Anderson, R. E., Tatham, R. L. \& Black, W. C. (1998) Multivariate data analysis (5th ed) Upper Saddle River: Prentice Hall.

[16]. Hatfield, R. (2006). Collegiality in higher education: Toward an understanding of the factors involved in collegiality. Journal of Organizational Culture, Communications and Conflict,10(1), 11-19. http://unesdoc.unesco.org.

[17]. Ishengoma, J. M. (2007). Internal Brain and its Impact on Higher Education Institution Capacity Building \& Human Resource Development In Sub Saharan Africa. Paper presented at the Conference of Rectors and Presidents of African Universities, (COREVIP).

[18]. Kamoche, K. N. (2001). Human resource management in Kenya in P. S. Budhwar and Y. A. Debrah, (eds) Human resource management in developing countries.London: Routledge

[19]. Kipkebut D.J.(2010). Organizational commitment and job satisfaction in higher education institutions: a Kenyan case. Middlesex University in In, K. N. (2001). Human resource management in Kenya

[20]. Kirk, J. \& Miller, M.L (1986).Reliability and Validity in Qualitative Research. Beverly Hills: Sage Publications.

[21]. Mihyo. P. (2007). Staff Retention in African Universities and Links with Diaspora Study. Report for the Association for the Development of Education in Africa Working Group on Higher

[22]. Muhammad, A. S. Bano S. Qazi Habib R. \& Humayoun A. A. (2010).Schematizing Talent Management, A Core Business Issue: (Study Of The Factors That Impacts On Talent Management In The Corporate Sector Of Islamabad, Pakistan) Far East Research center, Hong Kong.

[23]. Nunnally, J. C. (1967). Psychometric theory. New York: McGraw-Hill

[24]. Pallant, J. (2005) SPSS Survival Manual: A Step By Step Guide To Data Analysis Using SPSS For Windows Version 12, $2^{\text {nd }}$ Edition.Maidenhead: Open University Press.

[25]. Patton, M.Q (2002). Qualitative Evaluation and Research Methods ( $3^{\text {rd }}$ ed.) Thousand Oaks, CA: Sage Publication, Inc

[26]. Polonsky, M.J. \& Waller D.S. (2009). Designing and Managing a Research Project. Tejeshwer Deunique, New Delhi.

[27]. Rowley, J. (2009). Motivation and academic staff in higher education, http://www.emeraldinsight.com.

[28]. Schulze, S. (2008).Academic research at a South African higher education institution: Quality issues. Department of Further Teacher Education University of South Africa. Pretoria, South Africa. Unisa Press ISSN 1011-3487 pg 629-661

[29]. Schwart, R. Skinner, M. and Bowen,Z. (2009). Faculty Governing Boards and Institutional Governance: Advancing Higher Education, TIAA CREF Institute Publisher.

[30]. Schwarz, J. (2011). Research Methodology: Tools; Applied Data Analysis (with SPSS). Hochschule Luzern. Lurcern University.

[31]. Tabachnick, B. G. \& Fidell, L. S. (2001) Using multivariate statistics. Allyn and Bacon, Boston.

[32]. Tettey, W. J. (2006). Staff Retention in African Universities: Elements of a Sustainable Strategy. Washington DC: World Bank.

[33]. Thornton, S. (2011). It's not over yet. The annual report on the economic status of the profession.Academe, 97(2), 4-36.

[34]. Torrington, D., Hall, L. \& Taylor, S. (2008). Human Resource Management. Harlow: Pearson Education Ltd.

[35]. Zhang, L. \& Liu, X. (2010). Faculty employment at four-year colleges and universities. 